\title{
Landrace added value and accessibility in Europe: what a collection of case studies tells us
}



Received: 14 July 2020 / Revised: 19 January 2021 / Accepted: 21 January 2021 /

Published online: 11 February 2021

(c) The Author(s) 2021

\begin{abstract}
In the actual climate change scenario, in situ conservation of plant genetic resources for food and agriculture can significantly contribute broadening the diversity of our food system as well as increasing its resilience; nevertheless, landrace cultivation has been dramatically reduced in the last decades all over Europe. One of the most effective approaches to counteract the loss of landrace diversity in situ is facilitating its use. Aims of this study were to (i) describe how in situ maintenance of landraces occurs in different agro-environmental conditions in Europe and (ii) identify the main factors influencing landrace added values and accessibility as means to increase their adoption by new farmers. To the purpose, a collection of 95 case studies of both garden and open field landraces maintained in situ was analysed. A first description was obtained by classifying the information into 18 purposely defined categories. Data on landraces added values and accessibility were further transformed into weighted variables; the derived quantitative scores were then used as dependent variables in univariate and multivariate analyses. Results showed that farmers alone are still the main actors maintaining landraces in situ across different European biogeographical regions, mainly carrying out their activity under organic or low-input conditions, often in marginal areas. Results of the multivariate analysis showed that (i) type of actor involved in the multiplication, (ii) the main use of the product and (iii) presence of promotion actions significantly affect garden landraces added value and accessibility; presence of promotion actions was the only factor affecting added value of open field entries. Evidence arising from this work can contribute to the establishment of a fruitful ground of discussion for future European policies and strategies to protect and increase landrace use.
\end{abstract}

Keywords Landrace in situ conservation · Landraces · Case study methodology · Landrace added values $\cdot$ Landrace accessibility

Communicated by Daniel Sanchez Mata.

V. Negri

valeria.negri@unipg.it

1 Dipartimento di Scienze Agrarie Alimentari e Ambientali (DSA3), Università degli Studi di Perugia, Borgo XX Giugno 74, 06121 Perugia, Italy 


\section{Introduction}

Future food supplies depend on few major crops that are exposed to increasingly extreme and uncertain impacts of climate change (Nelson et al. 2009); in this scenario, we are facing an exceptionally high rate of biodiversity loss (FAO 2019). Biodiversity is central for resilience of ecosystems as it provides buffering effects to cope with drastic environmental fluctuations that affect communities within an ecosystem (Altieri 1999; Newton et al. 2009).

Agrobiodiversity - a subset of biodiversity that includes plant genetic resources for food and agriculture (PGRFA) — generally refers to the level of richness with regard to the number of species together with among- and within-species diversity, in a defined area. At species level, the presence of populations, different races and/or varieties, including their wild relatives, can counteract the current agrobiodiversity decline (CBD 1992; Maxted et al. 1997, 2002; Negri et al. 2009). Nowadays, a portion of agrobiodiversity is still managed and maintained in complex agroecosystems worldwide (van de Wouw et al. 2010), but progressively lost. Such loss is recognised as one of the major threats that agriculture faces as consequence of climate change (Lobell et al. 2008; FAO 2019).

Preservation of agrobiodiversity encompasses a range of diverse strategies and consequent actions to prevent loss of genetic, species and ecosystem diversity. Currently, a relevant portion of PGRFA is safely conserved ex-situ (i.e. in genebanks) since this conservation means has been regarded as the most practicable security measure 'to save as much as possible' from a short-term perspective (Gomez-Campo 1985). However, removing species, and their associated variability, from their environments of origin freezes their evolutionary and adaptive potential (Brush 2004; de Haan et al. 2013). A widely recognised solution to this issue is to integrate ex situ with in situ conservation by maintaining PGRFA in the areas where they have evolved over time and produced their distinctive traits (CBD 1992). This approach brings important advantages, in fact, its application can support functioning, resilience and, to some extent, productivity of agroecosystems (Tilman 1999, 2000).

In Europe, in situ conservation is generally associated with conservation of wild plants in protected areas; however, some actions focusing on landraces have been also carried out (Negri et al. 2013; Vetelainen et al. 2009). In the past, most of such actions arose locally or nationally and after a number of international documents and agreements (CBD 1992, 2010a, b; FAO 2001, 2012). Currently, through the formalisation of the EU Biodiversity Strategy for 2030 (European Commission 2020), the EU has created a favourable environment for the development of coordinated strategies to facilitate conservation of landraces and their sustainable use.

Although most of European agricultural production has been relying on registered and uniform cultivars, landraces, obsolete cultivars, and also other non-uniform varieties are still grown on-farm and in home gardens, i.e. in situ (Negri et al. 2009; Galluzzi et al. 2010). However, to date, no systematic studies were carried out to depict in situ conservation and use of landraces in Europe; in fact, diverse conservation situations and actors maintaining these materials make their systematic tracking rather complex and challenging at the same time. On the other hand, understanding and properly maintaining such diversified agricultural systems can favour equitable mechanisms of income generation and help society to better benefit of these resources, hence improving livelihoods and well-being (Bellon et al. 2015), whilst facing the challenge posed by the 
effects of climate change (Bellon et al. 2017). It is also noteworthy that landraces still hold great variability that can support future crop improvement for sustainable farming systems (Caproni et al. 2019).

Most importantly, understanding which factors increase (i) added value of landrace products and (ii) access to their propagation materials (e.g. seeds or seedlings), can favour the establishment of appropriate policies promoting use and adoption of landraces by new farmers across Europe, in line with the principles of its Biodiversity Strategy (European Commission 2020). Understanding the state of in situ conservation of landraces across Europe is not only a matter of collecting information about where and how these resources are cultivated, but also of recognising mechanisms and actions that have been put in place to favour their cultivation; for example, in other regions, collective market actions and ad hoc labelling strategies already created virtuous landrace in situ conservation conditions (Devaux et al. 2009; Krishna et al. 2010).

In order to get insights on the current situation about landrace in situ conservation, there are two possible general approaches. The first would privilege quantitative analysis of few variables across large samples (nomothetic approach) while the other would focus on qualitative, multi-aspect, in depth study of one or few case studies (idiographic approach). This difference brings to the key matter of studying many issues in few cases or few issues in many observations. On the other hand, the use of the so-called 'case study methodology' (CSM) can bridge the gap between nomothetic and ideographic methods and transcend, to a certain extent, their specific limitations (Larsson 1993). CSM takes advantage of the ability of case studies to deal with processual and multiple stakeholder considerations through multisource data; the nature of case studies and their complexity can make statistical examination of patterns, through different situations, rather difficult. However, this method tries to overcome this limitation by considering large sets of case studies.

In this work CSM was used to perform quantitative analysis on a large collection of case studies, gathering information about different in situ maintained landraces crossing a range of different socio-economic, pedo-climatic and cultural contexts in Europe as such offering insights that might not be achieved using other methodological approaches. In particular, the application of this methodology, allowed to summarise some of the major elements affecting in situ maintenance of landraces in Europe and the conditions that influence their added value and accessibility, both key factors that can contribute increasing adoption of landraces by next generations of farmers.

\section{Materials and methods}

\section{Landraces}

In the literature the term landrace refers to a broad range of different definitions that have evolved over time (Casañas et al. 2017; Negri et al. 2009; Negri, 2003, 2005; Camacho Villa et al. 2005; Asfaw 2000; Zeven 1998; Harlan 1975; Anderson and Cutler, 1942; von Rümker 1908).

A recent approach-formalised into the Concept for on-farm conservation and management of PGRFA by the European Cooperative Programme for Plant Genetic Resources (ECPGR 2017) — rather than giving additional and/or broader definition to the term landrace itself, focused on different materials that are maintained in situ: (i) true landraces (i.e. sensu stricto, Polegri and Negri 2010; Negri et al. 2009); (ii) introduced landraces (i.e. 
allochthonous, Zeven, 1998); (iii) selection from landraces (Raggi et al. 2019); (iv) crosscomposite populations and varietal mixtures (European Commission 2014; Goldringer et al. 2006; Raggi et al. 2016a, b); (v) historical varieties (Klaedtke et al. 2017). Being characterised by a certain level of genetic heterogeneity, all the above-mentioned materials-hereafter landraces intended in a broad sense-were the object of this study.

\section{Collection of case studies}

Case studies analysed in this work were retrieved from the public repository In situ landraces: best practice evidence-based database, hosted by the ECPGR and available at https://www.ecpgr.cgiar.org/in-situ-landraces-best-practice-evidence-based-database. The online database encompasses a number of case studies of in situ maintained landraces, representing successful (or potentially successful) examples of use, management and valorisation of these resources.

When possible, information from the online database was integrated with further data from literature (Tosti and Negri 2005; Theobald et al. 2006; Negri and Tiranti 2010; Torricelli et al. 2013; Plans et al. 2013; Ciancaleoni et al. 2014; Gouveia et al. 2014; Raggi et al. 2017; Figás et al. 2017; Leino et al. 2018; Caproni et al. 2018).

\section{Data classification}

As from the original structure of the database, the units of analysis of this research are 'the case studies', each referring to a distinct in situ maintained landrace. Information of each case study was initially classified into 18 purposely defined categories (Table 1). Altogether, the defined categories, describe basic characteristics and cross-sectional features that show how and where landraces are cultivated, managed, promoted on the market and accessed. The case studies were categorised according to their description by ascertaining the presence of single or multiple sentences showing clear correlation with categorical values in each defined category (Table 1).

In particular, the first six categories describe basic features such as local name, taxonomic classification, type of in situ conserved resource, location where cultivation occurs and mating system of each species (Table 1). The following three (7-9, Table 1) describe actors managing the landraces, their main uses and actions to promote their products. Categories from 10 to 12 describe the agronomic contexts where landraces are cultivated and some of their management features; categories from 13 to 15 are about market extent and use of geographical indications or other labels to add value to landrace products. The last three (from 16 to 18 ) categorise factors that can increase landrace accessibility and their potential adoption by new farmers (Table 1).

Due to the positive effects that product added value and improved accessibility can have in increasing current and future use of landraces - by increasing the value of their product and the number of actors able to access their propagation materials - the categories describing these aspects, added value (13-15) and accessibility (16-18), were converted into weighted variables. This transformation allowed to weight differences among categorical values in creating added value or improving access to propagation materials (Table 2).

In particular, as for categories defining the added value, an increasing value from 1 to 7 was assigned from products having no market, used for self-supply only (value $=1$ ), up to products characterised by an international market (value $=7$ ) passing through local (value $=3$ ) and national market (value $=5$ ) (Table 2). The selected weighted values 


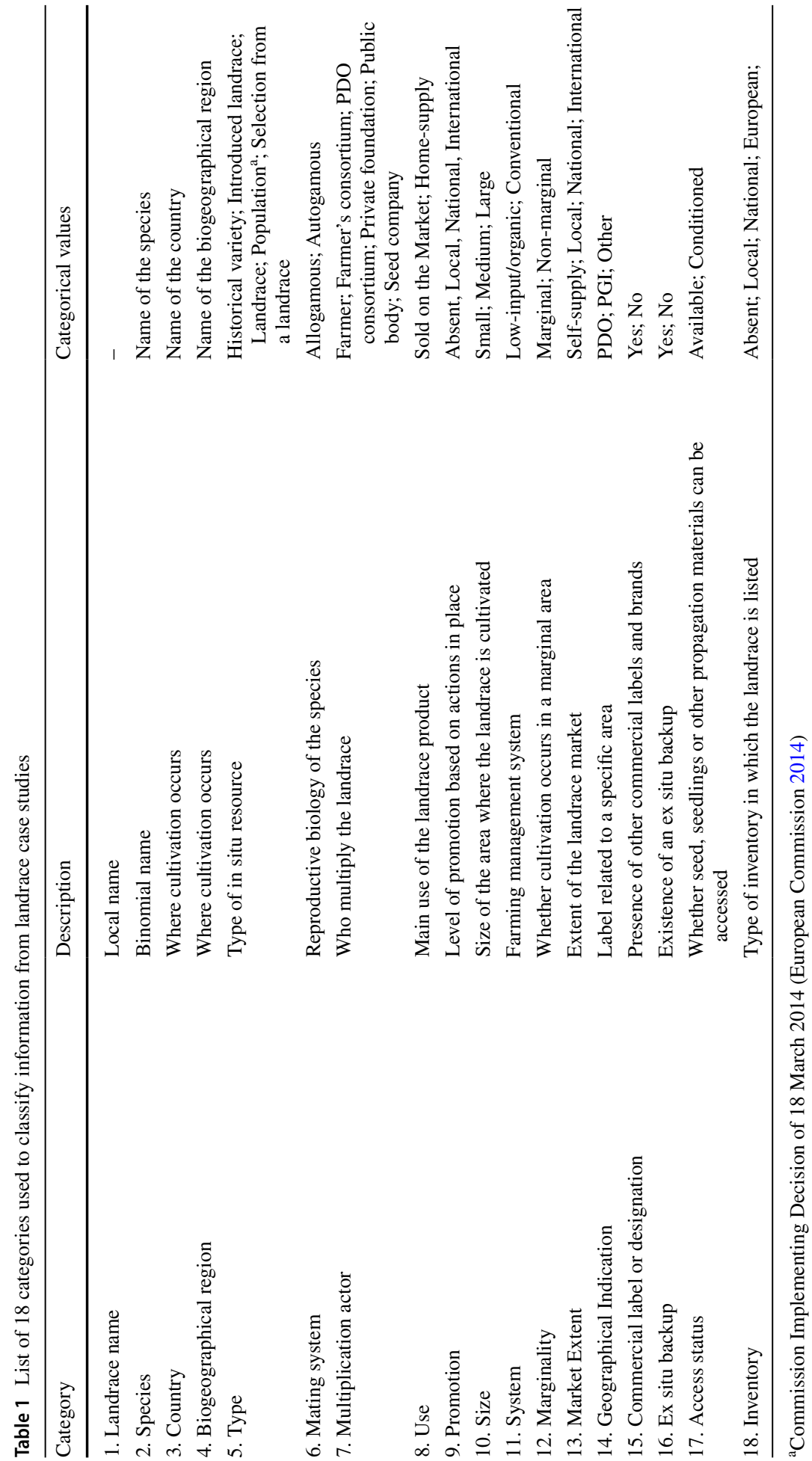


Table 2 List of categories, categorical values and their corresponding weighted variables used to calculate 'Added Value Quantitative Score' (AddValQS) and 'Access Quantitative Score' (AccQS)

\begin{tabular}{|c|c|c|}
\hline Category & Categorical value & Weighted value \\
\hline \multicolumn{3}{|c|}{ 'Added Value Quantitative Score' (AddValQS) } \\
\hline \multicolumn{3}{|c|}{ 13. Market extent } \\
\hline & Self-supply & 1 \\
\hline & Local & 3 \\
\hline & National & 5 \\
\hline & International & 7 \\
\hline \multicolumn{3}{|c|}{ 14. Geographical indication } \\
\hline & No geographical indication & 0 \\
\hline & PDO; PGI; Other & 5 \\
\hline \multicolumn{3}{|c|}{ 15. Commercial label or designation } \\
\hline & No label or designation & 0 \\
\hline & Yes & 3 \\
\hline \multicolumn{3}{|c|}{ ‘Access Quantitative Score’ (AccQS) } \\
\hline \multicolumn{3}{|c|}{ 16. Ex situ backup } \\
\hline & Absent & 0 \\
\hline & Present & 5 \\
\hline \multicolumn{3}{|c|}{ 17. Access status } \\
\hline & Conditioned & 1 \\
\hline & $\begin{array}{l}\text { Available on the seed or seedling } \\
\text { market }\end{array}$ & 7 \\
\hline \multicolumn{3}{|c|}{ 18. Inventory } \\
\hline & Absent & 0 \\
\hline & Local & 1 \\
\hline & National & 3 \\
\hline & European & 5 \\
\hline
\end{tabular}

reflect the idea that an increasing market extent can directly contribute to add value to a local product allowing to reach a larger number of potential consumers. Regarding labels, it has been demonstrated that concerning high quality food products, consumers value more those holding a Geographical Indication (GI), in comparison to nonGI labelled products (Menapace et al. 2009). In addition, the promotion of linkages between local producers, their local areas and their food products through GIs has been recognised as a crucial pathway to nutritious food systems and sustainable development for rural communities by both Food and Agriculture Organisation (FAO) and the European Bank for Reconstruction and Development (Vandecandelaere et al. 2018). For these reasons, a weighted value of 5 was assigned to landrace products holding a GI label while of 0 to those without any. Similarly, a weighted value of 3 was assigned to products holding other types of quality labels while of 0 to those without (Table 2). As for categories defining accessibility of landraces propagation material, the highest weighted value (7) was only assigned to entries for which seeds or seedlings are available on the market (Table 2); indeed, in these cases, a relevant number of seeds or seedlings is expected to be accessible with no restrictions. On the contrary, a lower weighted value (5) was assigned to landraces whose propagation material can only be accessed 
from ex situ storage facilities due to some limitations imposed to their access, such as the signature of a Standard Material Transfer Agreement, and low number of seeds that can be retrieved from gene banks. Finally, increasing weighed values were assigned to landraces listed in local, national or international inventories (1, 3 and 5, respectively) since the inclusion in such lists can help landraces to reach potential users at local, national or international level. Weighed values were assigned to each entry according to the corresponding categorical values (Table 2).

For each entry, an 'Added Value Quantitative Score' (AddValQS) was calculated as the sum of the assigned weighted values for the categories from 13 to 15 (Table 2); the same procedure, applied to categories from 16 to 18 (Table 2), was used to estimate the 'Accessibility Quantitative Score' (AccQS).

\section{Data analysis}

A general picture of the dataset was initially obtained by calculating the distributions of the case studies into the 18 categories, expressed as percentages. For each case study, average latitude and longitude of the cultivation area were retrieved and imported into GIS. The distribution of the landrace cultivation areas into the different European biogeographical regions was obtained by mapping the entries against 'the cartographic elaboration of the European biogeographical regions', obtained from the European Environment Agency web site (https://www.eea.europa.eu/data-and-maps/data/biogeographical -regions-europe-3).

In order to reduce complexity of the dataset, and make comparisons among more homogeneous groups, case studies were divided into garden and open field entries according to their usual classification and not on the average size of the area in which a specific landrace is cultivated.

In the univariate analysis, differences in medians of AddValQS and AccQS among the categories Multiplication actor, Use and Promotion were initially tested by means of nonparametric Kruskal-Wallis test (Rohlf and Sokal 1980). In addition, to test the effect of a specific categorical value of the same categories on AddValQS and AccQS, a set of binary variables were created (Calvet-Mir et al. 2011) as follows: (1) Multiplication actor, took the value of 1 if the landrace is multiplied by 'Farmers' and 0 otherwise; (2) Use, took the value of 1 if the landrace is mainly used as 'Home-supply' and 0 otherwise and (3) Promotion, took the value of 1 if the level of promotion of the landrace is limited to maintainers or local actors only and 0 otherwise. In the multivariate analyses, the above-described binary variables were used as independent variables against AddValQS and AccQS, used as dependent variables. In the analysis, distinct models were tested for garden and open field entries and case studies characterised by $\geq 1$ missing data were not included.

\section{Limitations}

The dataset analysed in this work is vast and complex, encompassing entries of different crops species cultivated using different agricultural practices and, most notably, cultivated for different purposes. In addition, the unit of analysis is 'the landrace', not 'the farm', 'the farmer' nor 'the gardener'; this limit questions that can potentially be addressed. Finally, not all the European countries are covered. 


\section{Results}

\section{The collected case studies}

A number of 95 case studies (hereafter entries) were retrieved from a total of 105; the remaining 10 case studies were discarded being related to non-European materials (Bellon and Brush 1994) or to fruit trees, which investigation is beyond the scope this work.

Entries belong to 46 different crop species classified as garden and open field; the most represented crops are: Solanum lycopersicum (tomato, 12), Phaseolus vulgaris (common bean, 8) and Secale cereale (rye, 6); 8 cereal entries belonging to the Triticum genus are also present (Table 3).

The collection encompasses entries from 15 different European countries; Italy, Spain and Hungary are represented with the highest number: 16, 13 and 13, respectively (Table 3). As from the geographical distribution of entries across Europe, almost all the main European biogeographical regions are covered: Mediterranean (31 entries), Continental (16), Atlantic (14), Pannonian (14), Boreal (11), Alpine (7) and Macaronesia (2) (Fig. 1). Garden entries appear to be mostly located in southern Europe while, for open field, no clear geographical distribution can be observed (Fig. 1).

Most of the case studies were classified as 'Landrace' (i.e. true landraces) (73.9\%) followed by 'Introduced landrace' (20.7\%), 'Historical variety' (3.3\%), 'Selection from a landrace' (1.1\%) and 'Population' (1.1\%) (total number of entries with available information $\mathrm{n}=92$ ). The $50.5 \%$ of the case studies describe landraces belonging to species characterised by a predominantly autogamous mating system, while $49.5 \%$ are predominantly allogamous $(\mathrm{n}=95)$.

Farmers - single $(84.1 \%)$ or grouped in consortia (6.8\%) — are the main actors carrying out landrace multiplication $(\mathrm{n}=88)$. The $27.4 \%$ of the entries resulted mostly cultivated for 'Home-supply' while the rest for commercial purposes $(n=95)$. According to the categorised data, the level of promotion (based on actions supporting the landrace) is 'Absent' in the $20.7 \%$, 'Local' in $39.5 \%$, 'National' $34.1 \%$ and 'International' in the $6.1 \%$ of the entries $(\mathrm{n}=81)$.

When the relative size of the cultivation area is considered $46.8 \%$ of entries are categorised as 'Small', 39.4\% 'Medium' and 13.8\% 'Large' $(n=94)$. Most entries (83.3\%) are cultivated under 'Low-input/organic' conditions and the others following conventional agronomic practices $(16.7 \%)(n=72)$. Interestingly, about half of the entries $(43.3 \%)$ is cultivated in marginal areas (i.e. areas characterised by unfavourable conditions) $(n=90)$. The full list of 95 case studies with the corresponding categorical values is available in Table S1 (Supplementary Materials).

Raw or processed landrace products are mainly commercialised in local markets $(58.9 \%)$ and, to a minor extent, at national level (23.3\%), while a lower but significant portion is cultivated by gardeners or farmers only to satisfy their needs $(14.4 \%)$; in few cases the products are commercialised in other countries (international markets, 3.3\%) $(n=90)$. In most cases no geographical indication to promote raw or processed products on the market is reported $(82.1 \%)$; indeed, only few entries hold a EU geographical indication $(10.6 \%)$ or other types of geographical indication $(7.4 \%)(n=95)$. However, for $35.4 \%$ of the case studies other types of commercial indications or brands are present such as 'Slow Food Presidium', 'Green heritage' and 'Pro Specie Rara'. Finally, only six case studies hold a geographical indication and another brand or indication at the same time. Regarding accessibility of seed or seedlings, most of landraces can be obtained through ex situ 


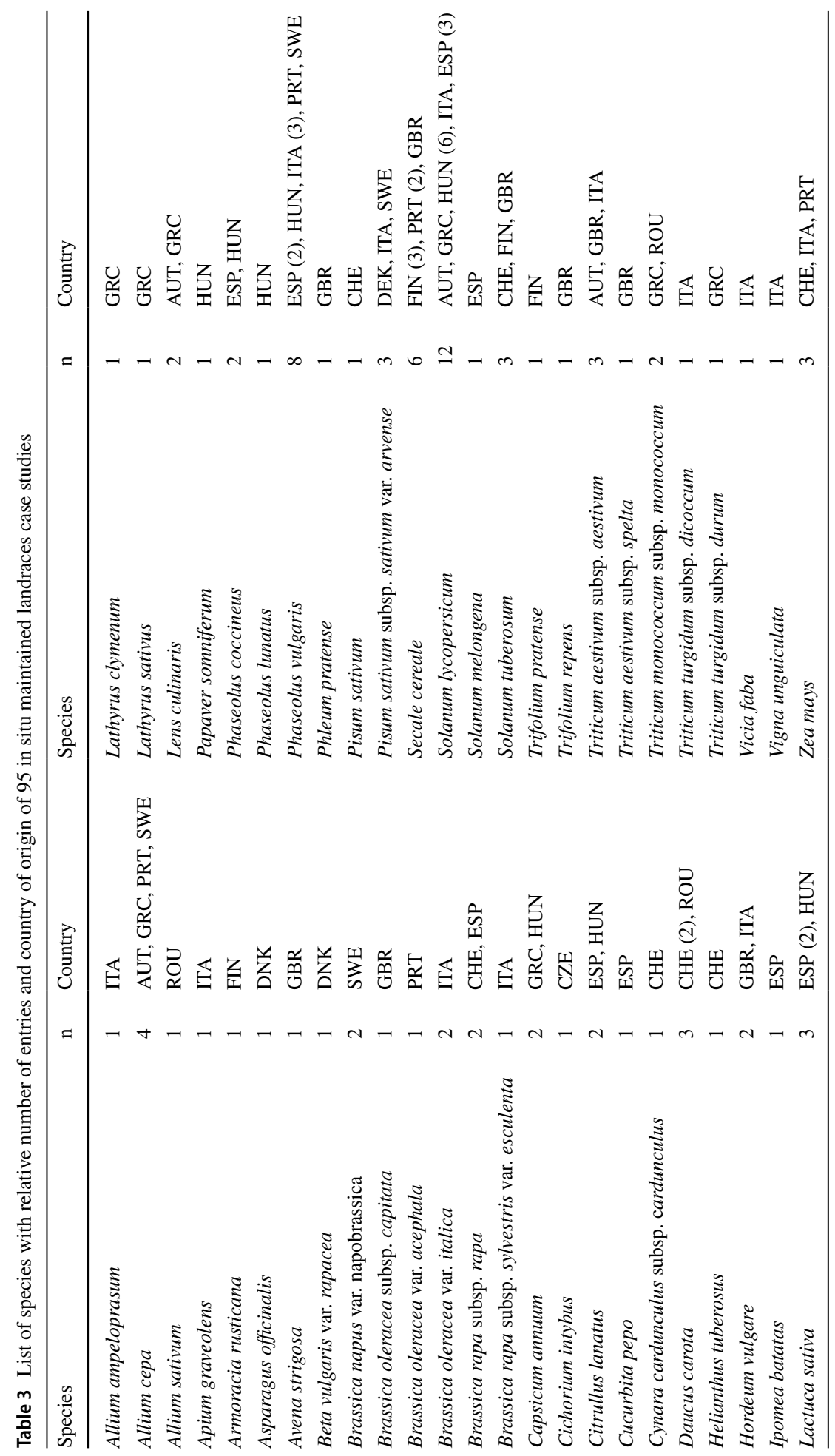






Fig. 1 Geographical location of the 95 entries within respective biogeographical regions. Entries are displayed as dots and coloured according to crop type as showed in the legend. Due to dots overlapping, multiple records with similar geographic coordinates can appear as a single dot

facilities, being already present in genebanks $(91.4 \%)(\mathrm{n}=70)$; notably, some of them can also be found on the seed or seedling market, being commercialised as conservation varieties (32.7\%) (European Commission 2008), amateur varieties (1.0\%) (European Commission 2009) or populations (1.0\%) (European Commission 2014). In the other cases it is unclear how seeds or seedlings can be accessed. Whether $17.0 \%$ of entries is not present in any register, others are listed in 'Local' (12.8\%), 'National' (22.3\%), 'European' (17.0\%) registers $(n=95)$.

\section{Added values and accessibility quantitative scores}

When garden entries are considered, the added value quantitative score (AddValQS) reached a maximum value of 15 in the case of the Italian Aglione della Val di Chiana (Allium ampeloprasum) - the only landrace characterised by having an international market and both geographical indication and commercial labels-followed by the broccoli Broccolo Fiolaro di Creazzo (13) and the Finnish potato Puikula (12). Among open field entries, highest AddValQS characterise the bread wheat Solina (13), the maize Rheintaler Ribelmais (10) and the grass pea Fava Feneou (10). Regarding the accessibility quantitative score (AccQS) more than one entry scored the maximum value (17): six garden tomatoes from Hungary, the pepper Glikokafteri Mpachovou and, among open field entries, the maize Nostrano di Storo, the barley Mix48, the einkorn wheat Kaploutzas and the emmer 

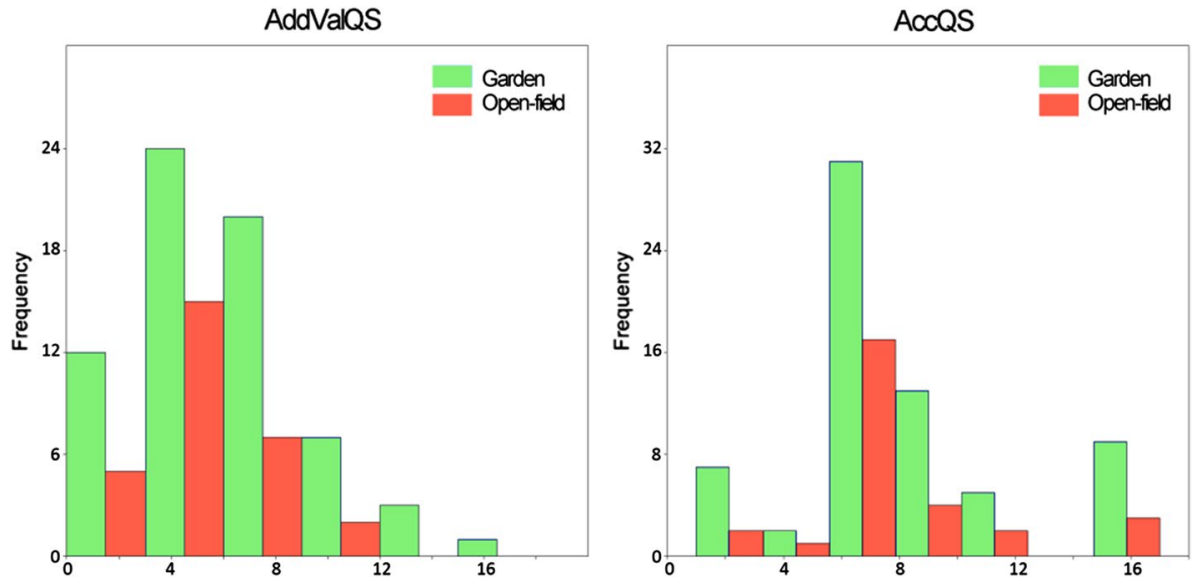

Fig. 2 Distributions of quantitative scores measuring added value (AddValQS) and accessibility (AccQS) of the 95 analysed in situ landraces

Table 4 Results of multivariate analysis for garden $(n=51)$ and open field entries $(n=25)$

\begin{tabular}{|c|c|c|c|c|c|c|c|c|}
\hline & \multicolumn{4}{|l|}{ Garden } & \multicolumn{4}{|l|}{ Open field } \\
\hline & \multicolumn{2}{|l|}{ AddValQS } & \multicolumn{2}{|l|}{ AccQS } & \multicolumn{2}{|l|}{ AddValQS } & \multicolumn{2}{|l|}{ AccQS } \\
\hline & Coefficient (SE) & $P$ & Coefficient (SE) & $P$ & Coefficient (SE) & $P$ & Coefficient (SE) & $P$ \\
\hline $\begin{array}{l}\text { Multiplication } \\
\text { actor }\end{array}$ & $-3.65(1.183)$ & $* *$ & $0.32(1.674)$ & ns & $1.18(1.622)$ & ns & $-4.19(2.243)$ & $\bullet$ \\
\hline Use & $-3.36(0.881)$ & $* * *$ & $2.88(1.247)$ & $*$ & $0.23(1.848)$ & ns & $-4.47(2.555)$ & $\bullet$ \\
\hline Promotion & $-2.26(0.875)$ & $*$ & $-2.82(1.237)$ & $*$ & $-3.23(1.183)$ & $* *$ & $0.58(1.636)$ & ns \\
\hline $\mathrm{R}^{2}$ & 0.42 & $* * *$ & 0.19 & $*$ & 0.28 & ns & 0.22 & ns \\
\hline
\end{tabular}

Not significant (ns); significant at $P \leq 0.1(\bullet) ; P \leq 0.05(*) ; P \leq 0.01(* *)$ and $P \leq 0.001(* * *)$

wheat Saritsam (Table S2, Supplementary Materials). Distributions of AddValQS and AccQS values among garden and open field entries are reported in Fig. 2.

\section{Factors affecting landrace added values and their accessibility}

Regarding garden crops, results of the Kruskal-Wallis test revealed the existence of significant differences among medians of the AddValQS for Multiplication actor $(P \leq 0.05$, $\mathrm{n}=59)$, Use $(P \leq 0.001, \mathrm{n}=62)$ and Promotion $(P \leq 0.001, \mathrm{n}=55)$, while AccQS values were different among medians of the category Promotion $(P \leq 0.05, \mathrm{n}=55)$. Regarding open field crops, AddValQS was only different among categorical values of Promotion $(P \leq 0.05, \mathrm{n}=32)$, while AccQS among the categorical values of Use $(P \leq 0.05, \mathrm{n}=41)$.

Results of the multivariate regressions (Table 4), where the explanatory variables Multiplication actor, Use and Promotion-coded as binary-were considered at the same time, were quite consistent with those obtained in the univariate analysis.

In particular, the added value quantitative score (AddValQS) of garden entries increases when: 
- the multiplication is carried out by consortia, seed companies or public bodies. In other words, it is expected that when the seed or seedling production of a landrace is managed by organised actors, instead of non-organised farmers, the final product has wider market and holds single or multiple indications or brands;

- the use of the landrace is mainly intended for the market, meaning that it is rather difficult that a landrace used for self-supply holds a geographical or a commercial label;

- the promotion has been developed at National or International level, in comparison to local promotion or absence of promotion, meaning that extensive promotion actions positively affect market size and labels held by a certain landrace.

For the same type of entries (garden) accessibility quantitative score (AccQS) increases when:

- entries are used for self-supply being frequently in ex situ collections, listed in registers or sold on the market;

- promotion has been carried out at national or international level, in comparison to no or local promotion, meaning that when a landrace underwent international or national promotion actions it is likely to be more accessible for potential new users.

Regarding open field entries, promotion at national or international level is the only factor positively affecting the added value quantitative score (AddValQS); it means that also for open field entries promotion actions positively affect market size and presence of labels (Table 4). None of the three factors significantly affects accessibility quantitative scores (AccQS) (Table 4). In this case, the low number of case studies strongly reduced our ability to predict open field entries AddValQS and AccQS starting from the values of the three considered binary variables.

\section{Discussion}

This collection of 95 case studies gives a cross-sectional picture of some of the key features that can contribute sustaining and possibly increase landrace cultivation across Europe. Indeed, a better understanding of factors positively affecting added value and accessibility of such genetic resources can be the ground of discussion for future measures aiming at improving the wealth of landrace cultivation. In fact, it has been already suggested that an effective, sustainable and long-term in situ conservation of landraces can only occur with adoption in cultivation by new farmers (Casañas et al. 2017; Maxted et al. 2009); these conditions are fostered when landraces are characterised by an appealing market potential (i.e. added values) and by clear rules and protocols that favour their accessibility (Spataro and Negri 2013). Today, the need of passing landraces in the hands of new generations is more important than ever, as a matter of facts it has been shown that European farmers using landraces are elderly (Calvet-Mir et al. 2011).

From the beginning, the idea behind the analysis of a large set of case studies was to include as much information as possible about the main features that characterise in situ conservation of crops' diversity. This brought the need of including, together with true landraces, examples of a range of different cultivated materials such as introduced landraces, historical varieties, selections from landraces and other types of populations that also encompass an intrinsic genetic diversity. Indeed, nowadays, cultivation and use of these 
materials is seen as positive means to foster a diversified and more sustainable food system, able to support, to a certain extent, healthy agro-ecosystems, their functioning, resilience and productivity, especially in low-input conditions (ECPGR 2017). The CSM approach used in the present study helped in overcoming major drawbacks of single case study analysis, that is usually characterised by the inability of examining cross-sectional themes and to generalise conclusions and findings to large and diversified systems (Larsson 1993). For this reason, even considering the complexity of this topic, we are fairly confident that the evidence arising from this work well describes the context of in situ conservation of landraces as well as its diversified features. Indeed, collated information covers many diverse in situ conservation contexts that characterise Europe; in fact, as many as 46 crop species, of both garden and open field crops, are represented and the case studies are well distributed over the main European biogeographical regions.

Results of this research indicated that landrace cultivation frequently occurs in marginal areas contributing to the income of farmers working in conditions in which conventional agriculture cannot be easily carried out. Landraces, and especially true landraces - the majority of entries in this study — have adapted, and are continuously adapting, to the specific environmental conditions in which they have been cultivated. For this reason, such materials are of particular interest for marginal areas as well as for being used under organic and low-input management systems, where few external inputs are available for counteracting limiting factors. As a matter of facts, most of entries in our dataset are cultivated under organic or low input conditions.

Going deep into the case study descriptions it emerges that several entries seem to be characterised by peculiar adaptive traits making their cultivation still attractive in specific pedo-climatic conditions. For example, tolerance to different types of limiting factors are reported for many entries. One of the most interesting examples is the Greek tomato landrace Tomataki Santorinis, traditionally cultivated in the volcanic island of Thira (Santorini), where soil is poor in organic matter and water, and plants undergo stressful conditions also due to high temperatures and radiation (Koutsika-Sotiriou et al. 2016); another example is the Austrian onion landrace Laaer Zwiebel that can be cultivated without any irrigation. Among the conservation varieties, the Finnish Hermanni and Iivo rye landraces are characterised by winter hardiness and Italian Solina wheat by adaptation to the specific conditions of the mountain area where it is cultivated (Porfiri et al. 2001).

There is evidence in the literature that local actions like local fairs (Castellini 2005), meals associated with particular recurrences (Papa 1999) and contests for the best landrace product (Mendes-Moreira et al. 2014) have a positive impact on the maintenance of landraces in situ (Negri 2012). Our data also showed that creation of added value is often linked to attribution of geographical indications (e.g. PDO, PGI), trademarks and quality labels. Such labels ascertain the uniqueness of the landrace product-in comparison with others-its particular traits, the link with the cultural and traditional values of the territory or, simply, the way it was obtained. However, the use of a geographic indication resulted not so extensive in the analysed dataset suggesting that there is still room for improvement. In some recent reports FAO (2009) showed that geographical indications can be used as a driver for a sustainable development of rural areas; indeed, geographical indications can link the European heritage of food diversity, genetic resources and local knowledge with the market dimension (Vandecandelaere 2011).

As from the description of the analysed case studies, a high number of landraces underwent different types of promotion initiatives so that we decided to test the effect of promotion on landraces added value (AddValQS) and access (AccQS) measured as quantitative scores; according to our results, promotion was the only factor increasing AddValQS and 
AccQS of both garden and open field entries (Table 4). Starting from this evidence-in order to make landraces more appealing and accessible to the next generation of European farmers-we would suggest that policies should leverage on actions promoting landraces at national and international level. The application of this strategy could rise landraces use in Europe as a consequence of the potential higher added value of their product and of an easier access to their propagation materials.

From our analysis, other key elements to sustain future cultivation of landraces across Europe emerged. Indeed, results showed that farmers are the main actors carrying out landrace multiplication being, the facto, the most relevant players in managing, using and conserving landrace diversity. From what we observed, seed companies have only a marginal role in producing and commercialising landrace seeds or seedlings. However, testing the effect of different multiplication actors against landraces added value and accessibility, it emerged that products derived from garden landraces have higher added values (AddValQS) when managed by farmer consortia, seed companies or public bodies while this effect was not observed for open field entries (Table 4). In other words, the creation of consortia around specific landraces can enhance added values of their commercial products resulting in a wider market and acquisition of geographical indications or labels, at least in the case of garden crops. In this regard, it is noteworthy that the European seed legislation frame offers several possibilities to register landraces as 'conservation varieties', 'amateur varieties' or 'populations' (European Commission 2008, 2009, 2014) favouring the involvement of private seed companies and other stakeholders in the use of landraces. Then, while a small portion of landraces took advantage of these potentially beneficial tools (Spataro and Negri 2013), registration might represent an important means to scale up conservation and accessibility, use and market of garden landraces. Indeed, when seeds or seedlings are present on the market the access is facilitated considering both possible use and the number of seeds/seedlings that can be retrieved. It has already been reported that landraces in situ conservation is favoured by incentives to farmers and collaboration with institutions and social organisations (Bellon 2004; Brush 2004; Zimmerer 2010); in this context an external source of support mainly assumed the form of promotion activities to increase added value and visibility of landrace products on the market, calling consumer attention and interest.

\section{Conclusions}

Future policies aimed at promoting landrace conservation and their sustainable use should leverage on strategies favouring promotion to add value and increase accessibility. Indeed, factors that positively affect these aspects should properly be considered when planning national or European actions that want to increase and promote use of landraces in situ. We believe that a joint European long-term strategy can foster in situ conservation by helping the transition of these resources to the next generation of farmers, on behalf of a future diversified European agriculture.

Supplementary Information The online version contains supplementary material available at https://doi. org/10.1007/s10531-021-02130-w.

Acknowledgements We wish to acknowledge all those who, beside the authors, contributed with case studies to the public database: A. Barata and J. Magos Brehm (Instituto Nacional de Investigação Agrária e Veterinária, Portugal); H. Meierhofer (Arche Noah, Austria); B. Bartha (ProSpecieRara, Switzerland); J. Fehér (The Hungarian Research Institute of Organic Agriculture, Hungary); S. Kell and N. Maxted (University of 
Birmingham, United Kingdom); V. Holubec (ECPGR national coordinator, Czech Republic); J. M. Iriondo Alegría (Universidad Rey Juan Carlos, Spain), J. Prohens, J.T., De Jesus Diez Nicols and S. Soler Aleixandre (Universitat Politècnica de València, Spain), M. Heinonen (Natural Resource Institute (LUKE), Finland), P. Ralli and K. Koutis (Hellenic Agricultural Organization-DEMETER, Greece); J. Weibull (Swedish Board of Agriculture, Sweden); G. Poulsen (Danish Seed Savers, Denmark). Authors also wish to acknowledge the two anonymous reviewers for their valuable suggestions.

Author contributions LR and LC equally contributed to this paper as first authors. Conceptualisation: VN and LR; Methodology and Formal analysis and investigation: LR and LC; Writing-review and editing: LR, LC and VN; Funding acquisition and Supervision: VN.

Funding Open Access funding provided by Università degli Studi di Perugia. This project was partially funded by the European Union's Horizon 2020 research and innovation programme under the Grant Agreement No: 774271 'Networking, partnerships and tools to enhance in situ conservation of European plant genetic resources' (Farmer's Pride).

\section{Compliance with ethical standards}

Conflict of interest The authors declare that they have no conflict of interest.

Open Access This article is licensed under a Creative Commons Attribution 4.0 International License, which permits use, sharing, adaptation, distribution and reproduction in any medium or format, as long as you give appropriate credit to the original author(s) and the source, provide a link to the Creative Commons licence, and indicate if changes were made. The images or other third party material in this article are included in the article's Creative Commons licence, unless indicated otherwise in a credit line to the material. If material is not included in the article's Creative Commons licence and your intended use is not permitted by statutory regulation or exceeds the permitted use, you will need to obtain permission directly from the copyright holder. To view a copy of this licence, visit http://creativecommons.org/licenses/by/4.0/.

\section{References}

Altieri MA (1999) The ecological role of biodiversity in agroecosystems. Agric Ecosyst Environ 74:19-31. https://doi.org/10.1016/S0167-8809(99)00028-6

Anderson E, Cutler H (1942) Races of Zea mays. L. their recognition and classification. Ann Missouri Bot Gard 29:69-88. https://doi.org/10.2307/2394331

Asfaw Z (2000) The barleys of Ethiopia. In: Brush S (ed) Genes in the field: on-farm conservation of crop diversity. IPGRI, Rome, pp 77-107

Bellon MR (2004) Conceptualizing interventions to support on-farm genetic resource conservation. World Dev 32:159-172. https://doi.org/10.1016/j.worlddev.2003.04.007

Bellon MR, Brush SB (1994) Keepers of maize in Chiapas, Mexico. Econ Bot 48:196-209. https://doi. org/10.1007/BF02908218

Bellon MR, Gotor E, Caracciolo F (2015) Conserving landraces and improving livelihoods: how to assess the success of on-farm conservation projects? Int J Agric Sustain 13:167-182. https://doi. org/10.1080/14735903.2014.986363

Bellon MR, Dulloo E, Sardos J et al (2017) In situ conservation-harnessing natural and human-derived evolutionary forces to ensure future crop adaptation. Evol Appl 10:965-977. https://doi.org/10.1111/ eva. 12521

Brush SB (2004) Farmers' bounty: locating crop diversity in the contemporary world. Yale University Press, London

Calvet-Mir L, Calvet-Mir M, Vaqué-Nuñez L, Reyes-García V (2011) Landraces in situ conservation: a case study in high-mountain home gardens in Vall Fosca, Catalan Pyrenees, Iberian Peninsula. Econ Bot 65:146-157

Camacho Villa TC, Maxted N, Scholten M, Ford-Lloyd B (2005) Defining and identifying crop landraces. Plant Genet Resour 3:373-384. https://doi.org/10.1079/pgr200591 
Caproni L, Raggi L, Tissi C et al (2018) Multi-environment evaluation and genetic characterisation of common bean breeding lines for organic farming systems. Sustainability 10:777. https://doi.org/10.3390/ su10030777

Caproni L, Raggi L, Ceccarelli S, Negri V, Carboni A (2019) In-depth characterisation of common bean diversity discloses its breeding potential for sustainable agriculture. Sustainability 11:5443

Casañas F, Simó J, Casals J, Prohens J (2017) Toward an evolved concept of landrace. Front Plant Sci 08:145. https://doi.org/10.3389/fpls.2017.00145

Castellini G (2005) Caratterizzazione genetica di una varietà locale di sedano da costa Apium graveolens L. var. dulce (Miller) Pers. PhD thesis, University of Perugia

CBD (1992) Convention on Biological Diversity: Text and Annexes. Secretariat of the Convention on Biological Diversity, United Nations environment program. Rio de Janeiro, Brazil. http://www.cbd.int/ convention/

CBD (2010a) Global Strategy for Plant Conservation. Secretariat of the Convention on Biological Diversity, United Nations environment program. Montreal, Canada. www.cbd.int/gspc/

CBD (2010b) Strategic Plan for Biodiversity 2011-2020. Secretariat of the Convention on Biological Diversity, United Nations environment program. Montreal, Canada. https://www.cbd.int/sp/

Ciancaleoni S, Raggi L, Negri V (2014) Genetic outcomes from a farmer-assisted landrace selection programme to develop a synthetic variety of broccoli. Plant Genet Resour 12:349-352. https://doi. org/10.1017/S1479262113000592

de Haan S, Núñez J, Bonierbale M et al (2013) A simple sequence repeat (SSR) marker comparison of a large In- and ex-situ potato landrace cultivar collection from peru reaffirms the complementary nature of both conservation strategies. Diversity 5:505-521. https://doi.org/10.3390/d5030505

Devaux A, Horton D, Velasco C et al (2009) Collective action for market chain innovation in the Andes. Food Policy 34:31-38. https://doi.org/10.1016/j.foodpol.2008.10.007

ECPGR (2017) ECPGR Concept for on-farm conservation and management of plant genetic resources for food and agriculture. ECPGR, Rome

Enjalbert J, Dawson JC, Paillard S et al (2011) Dynamic management of crop diversity: from an experimental approach to on-farm conservation. Comptes Rendus - Biol 334:458-468. https://doi. org/10.1016/j.crvi.2011.03.005

European Commission (2008) Commission Directive 2008/62/EC of 20 June 2008 providing for certain derogations for acceptance of agricultural landraces and varieties which are naturally adapted to the local and regional conditions and threatened by genetic erosion and for marketing of seed and seed potatoes of those landraces and varieties. OJ L 162, 21.6.2008: 13-19.

European Commission (2009) Commission Directive 2009/145/EC of 26 November 2009 providing for certain derogations, for acceptance of vegetable landraces and varieties which have been traditionally grown in particular localities and regions and are threatened by genetic erosion and of vegetable varieties with no intrinsic value for commercial crop production but developed for growing under particular conditions and for marketing of seed of those landraces and varieties. OJ L 312, 27.11.2009: 44-54.

European Commission (2014) 2014/150/EU: Commission Implementing Decision of 18 March 2014 on the organisation of a temporary experiment providing for certain derogations for the marketing of populations of the plant species wheat, barley, oats and maize pursuant to Council Directive 66/402/EEC (notified under document C(2014) 1681). OJ L 82, 20.3.2014: 29-36

European Commission (2020) Communication from the commission to the European Parliament, the Council, the European economic and social Committee and the Committee of the regions EU Biodiversity Strategy for 2030 Bringing nature back into our lives. COM(2020) 380 final. Brussels, Belgium.

FAO (2001) International Treaty on Plant Genetic Resources for Food and Agriculture. Food and Agriculture Organization of the United Nations, Rome

FAO (2012) Second Global Plan of Action for Plant Genetic Resources for Food And Agriculture. Food and Agriculture Organization of the United Nations, Rome, Italy, Rome

FAO (2019) The State of the World's Biodiversity for Food and Agriculture. In: Bélanger J, Pilling D (eds) FAO Commission on Genetic Resources for Food and Agriculture Assessments. FAO, Rome

Figás M, Raigón M, Casanova C et al (2017) Caracterización de una colección de variedades tradicionales valencianas de lechuga (Lactuca sativa L.). Frutic Hortic Floric 401:157-164

Galluzzi G, Eyzaguirre P, Negri V (2010) Home gardens: Neglected hotspots of agro-biodiversity and cultural diversity. Biodivers Conserv 19:3635-3654. https://doi.org/10.1007/s10531-010-9919-5

Goldringer I, Prouin C, Rousset M et al (2006) Rapid differentiation of experimental populations of wheat for heading time in response to local climatic conditions. Ann Bot 98:805-817. https://doi. org/10.1093/aob/mcl160 
Gomez-Campo C (1985) Seed banks as an emergency conservation strategy. In: Gomez-Campo C (ed) Plant conservation in the Mediterranean area. Springer, New York, pp 237-247

Gouveia CSS, Freitas G, De Brito JH et al (2014) Nutritional and mineral variability in 52 accessions of common bean varieties (Phaseolus vulgaris L.) from Madeira Island. Agric Sci 5:317-329. https:// doi.org/10.4236/as.2014.54034

Harlan JR (1975) Our vanishing genetic resources. Science 188:617-621. https://doi.org/10.1126/scien ce. 188.4188 .617

Klaedtke S, Caproni L, Klauck J et al (2017) Short-term local adaptation of historical common bean (Phaseolus vulgaris $\mathrm{L}$ ) varieties and implications for in situ management of bean diversity. Int $\mathbf{J}$ Mol Sci 18:493. https://doi.org/10.3390/ijms18030493

Koutsika-Sotiriou M, Mylonas I, Tsivelikas A, Traka-Mavrona E (2016) Compensation studies on the tomato landrace 'Tomataki Santorinis.' Sci Hortic 198:78-85. https://doi.org/10.1016/J.SCIEN TA.2015.11.006

Krishna VV, Pascual U, Zilberman D (2010) Assessing the potential of labelling schemes for in situ landrace conservation: an example from India. Environ Dev Econ 15:127-151. https://doi.org/10.1017/ S1355770X09990155

Larsson R (1993) Case survey methodology: quantitative analysis of patterns across case studies. Acad Manag J 36:1515-1546. https://doi.org/10.5465/256820

Leino MW, Solberg S $\varnothing$, Tunset HM et al (2018) Patterns of exchange of multiplying onion (Allium cepa L. Aggregatum-Group) in Fennoscandian home gardens. Econ Bot 72:346-356. https://doi.org/10.1007/ s12231-018-9426-2

Lobell DB, Burke MB, Tebaldi C et al (2008) Prioritizing climate change adaptation needs for food security in 2030. Science 319:607-610. https://doi.org/10.1126/science.1152339

Maxted N, Hawkes JG, Ford-Lloyd BV, Williams JT (1997) A practical model for in situ genetic conservation. In: Maxted N, Ford-Lloyd BV, Hawkes JG (eds) Plant genetic conservation: the in situ approach. Chapman \& Hall, London, pp 339-367

Maxted N, Guarino L, Myer L, Chiwona EA (2002) Towards a methodology for on-farm conservation of plant genetic resources. Genet Resour Crop Evol 49:31-46. https://doi.org/10.1023/A:1013896401710

Maxted N, Veteläinen M, Negri V (2009) Landrace Inventories: Needs and Methodologies. In: Veteläinen M, Negri V, Maxted N (eds) European landraces: on-farm conservation, management and use, bioversity technical bulletin 15 . Bioversity International, Rome, pp 1-359

Menapace L, Colson G, Grebitus C, Facendola M (2009) Consumer Preferences for Country-Of-Origin, Geographical Indication, and Protected Designation of Origin Labels. Staff General Research Papers Archive 13122, Iowa State University, Department of Economics.

Mendes-Moreira P, Mendes-Moreira J, Fernandes A et al (2014) Is ear value an effective indicator for maize yield evaluation? Food Crop Res 161:75-86. https://doi.org/10.1016/J.FCR.2014.02.015

Negri V (2003) Landraces in central Italy: Where and why they are conserved and perspectives for their onfarm conservation. Genet Resour Crop Evol 50:871-885. https://doi.org/10.1023/A:1025933613279

Negri V (2005) Agro-biodiversity conservation in Europe: Ethical issues. J Agric Environ Ethics 18:3-25. https://doi.org/10.1007/s10806-004-3084-3

Negri V (2012) Policies supportive of on-farm conservation and their impact on custodian farmers in Italy. In: Padulosi S, Bergamini N, Lawrence T (eds) On farm conservation of neglected and underutilized species: status, trends and novel approaches to cope with climate change. Bioversity international, Frankfurt, pp 211-217

Negri V, Tiranti B (2010) Effectiveness of in situ and ex situ conservation of crop diversity. What a Phaseolus vulgaris L. landrace case study can tell us. Genetica 138:985-998. https://doi.org/10.1007/s1070 9-010-9485-5

Negri V, Maxted N, Vetelainen M (2009) European landrace conservation: an introduction. In: Negri V, Maxted N (eds) Technical Bullettin n 15 European landraces: On-farm conservation, management and use. Bioversity International, Rome

Negri V, Pacicco L, Bodesmo M, Torricelli R (2013) The First Italian inventory of in situ maintained landraces. Morlacchi Editrice, Perugia, Italy. http://vnr.unipg.it/PGRSecure/start.html

Nelson GC, Rosegrant MW, Koo J et al (2009) Climate change: impact on agriculture and costs of adaptation. International Food Policy Research Institute, Washington

Newton AC, Begg GS, Swanston JS (2009) Deployment of diversity for enhanced crop function. Ann Appl Biol 154:309-322. https://doi.org/10.1111/j.1744-7348.2008.00303.x

Papa C (1999) Il farro a Monteleone di Spoleto: pratiche agrarie, consuetudini giuridiche e ritualità. In: Papa C (ed) Il Farro. Saperi, usi e conservazione delle varieta locali. CEDRAV, Cerreto di Spoleto, Italy, pp 9-26 
Plans M, Simó J, Casañas F et al (2013) Characterization of common beans (Phaseolus vulgaris L.) by infrared spectroscopy: comparison of MIR, FT-NIR and dispersive NIR using portable and benchtop instruments. Food Res Int 54:1643-1651. https://doi.org/10.1016/j.foodres.2013.09.003

Polegri L, Negri V (2010) Molecular markers for promoting agro-biodiversity conservation: a case study from Italy. How cowpea landraces were saved from extinction. Genetic Resour and Crop Evol 57:867880. https://doi.org/10.1007/s10722-009-9526-Z

Porfiri O, Torricelli R, Silveri DD et al (2001) The Triticeae genetic resources of central Italy: collection, evaluation and conservation. Hereditas 135:187-192. https://doi.org/10.1111/j.1601-5223.2001.00187 .X

Raggi L, Negri V, Ceccarelli S (2016) Morphological diversity in a barley composite cross-derived population evolved under low-input conditions and its relationship with molecular diversity: indications for breeding. J Agric Sci 154:943-959. https://doi.org/10.1017/S0021859615000921

Raggi L, Ceccarelli S, Negri V (2016) Evolution of a barley composite cross-derived population: an insight gained by molecular markers. J Agric Sci 154:23-39. https://doi.org/10.1017/S0021859614001269

Raggi L, Ciancaleoni S, Torricelli R, Terzi V, Ceccarelli S, Negri V (2017) Evolutionary breeding for sustainable agriculture: selection and multi- environmental evaluation of barley populations and lines. $\mathrm{F}$ Crop Res 204:76-88. https://doi.org/10.1016/j.fcr.2017.01.011

Raggi L, Caproni L, Carboni A, Negri V (2019) Genome-wide association study reveals candidate genes for flowering time variation in common bean (Phaseolus vulgaris L.). Front Plant Sci 10:962. https://doi. org/10.3389/fpls.2019.00962

Rohlf JF, Sokal RR (1980) Biometry: the principles and practice of statistics in biological research. WH Freeman and company, New York

Spataro G, Negri V (2013) The European seed legislation on conservation varieties: Focus, implementation, present and future impact on landrace on farm conservation. Genet Resour Crop Evol 60:2421-2430. https://doi.org/10.1007/s10722-013-0009-x

Theobald HE, Wishart JE, Martin PJ et al (2006) The nutritional properties of flour derived from Orkney grown bere barley (Hordeum vulgare L.). Nutr Bull 31:8-14

Tilman D (1999) Global environmental impacts of agricultural expansion: the need for sustainable and efficient practices. Proc Natl Acad Sci USA 96:5995-6000. https://doi.org/10.1073/pnas.96.11.5995

Tilman D (2000) Causes, consequences and ethics of biodiversity. Nature 405:208-211. https://doi. org/10.1038/35012217

Torricelli R, Tiranti B, Spataro G et al (2013) Differentiation and structure of an Italian landrace of celery (Apium graveolens L.): inferences for on farm conservation. Genet Resour Crop Evol 60:995-1006. https://doi.org/10.1007/s10722-012-9896-5

Tosti N, Negri V (2005) On-going on-farm microevolutionary processes in neighbouring cowpea landraces revealed by molecular markers. Theor Appl Genet 110:1275-1283. https://doi.org/10.1007/s0012 2-005-1964-1

van de Wouw M, Kik C, van Hintum T et al (2010) Genetic erosion in crops: concept, research results and challenges. Plant Genet Resour 8:1-15. https://doi.org/10.1017/S1479262109990062

Vandecandelaere E, Teyssier C, Barjolle D, Jeanneaux P, Fournier S, Beucherie O (2018) Strengthening sustainable food systems through geographical indications: an analysis of economic impacts. European Bank for Reconstruction and Development (EBRD).

Veteläinen M, Negri V, Maxted N (eds) (2009) European landraces: on-farm conservation, management and use. Bioversity technical bulletin 15. Bioversity International, Rome, pp 1-359

von Rümker K (1908) Die systematische Einteilung und Benennung der Getreidesorten für praktische Zwecke. Jahrb Dtsch 23:137-167

Zeven A (1998) Landraces: a review of definitions and classifications. Euphytica 104:127-139. https://doi. org/10.1023/A:1018683119237

Zimmerer KS (2010) Biological diversity in agriculture and global change. Annu Rev Environ Resour 35:137-166. https://doi.org/10.1146/annurev-environ-040309-113840

Publisher's Note Springer Nature remains neutral with regard to jurisdictional claims in published maps and institutional affiliations. 